\title{
SWELLING ON THE HARD PALATE PRESENTING AS POLYMORPHOUS LOW GRADE ADENOCARCINOMA: A CASE REPORT AND REVIEW OF LITERATURE
}

\author{
Swapnil D. Chandekar ${ }^{1}$, Sunita S. Dantkale², Rahul R. Narkhede ${ }^{3}$, Snehal V. Chavhan ${ }^{4}$, Khushboo Birla ${ }^{5}$
}

\section{HOW TO CITE THIS ARTICLE:}

Swapnil D. Chandekar, Sunita S. Dantkale, Rahul R. Narkhede, Snehal V. Chavhan, Khushboo Birla. "Swelling on the Hard Palate Presenting as Polymorphous Low Grade Adenocarcinoma: A Case Report and Review of Literature". Journal of Evolution of Medical and Dental Sciences 2014; Vol. 3, Issue 36, August 18;

Page: 9484-9488, DOI: $10.14260 /$ jemds/2014/3224

\begin{abstract}
Polymorphous Low Grade Adenocarcinoma (PLGA) is a relatively newer entity under the sub-classification of adenocarcinoma, which arises mainly from the minor salivary glands. PLGA is difficult to diagnose both clinically and histopathologically due to its indolent presentation and its morphological diversity that includes several microscopic patterns. It is an uncommon malignant neoplasm with low aggressiveness accounting for about $2 \%$ of all salivary gland tumours. We are reporting this case of PLGA which arose from the minor salivary gland over the hard palate.

KEYWORDS: Polymorphous Low Grade Adenocarcinoma, Pleomorphic adenoma, Adenoid cystic carcinoma.

INTRODUCTION: PLGA was first described in 1983 by Batsakis et al., as terminal duct carcinoma and Freedman et al., named it as lobular carcinoma. Evans and Batsakis, in 1984, eventually coined the term, Polymorphous Low Grade Adenocarcinoma (PLGA). [1] It was included under WHO classification of salivary gland tumours in 1990. PLGA is second most common intraoral malignant salivary gland tumour, accounting for about $2 \%$ of all salivary gland tumours. ${ }^{[1,2]}$ PLGA is a malignant neoplasm of salivary glands with low aggressiveness, exclusively found in minor salivary glands. ${ }^{[3]}$
\end{abstract}

CASE REPORT: A 65 years old female patient presented with a palatal swelling since 3 years. On examination non-tender, non-ulcerated mass of $4 \times 3 \mathrm{~cm}$ was seen attached to hard palate extending posteriorly into the soft palate. CT scan revealed a submucosal soft tissue mass over hard palate.

Grossly, it was a well circumscribed, non-encapsulated mass of $3.5 \times 2 \mathrm{~cm}$, firm in consistency [Fig-1]. Cut section was tan to gray-white.

Microscopic examination revealed a circumscribed tumour composed of cells arranged in tubules, tubuloglandular, trabeculae, lobules, single cell files (Indian file) and solid nests separated by fibrosclerotic stroma [Fig-2], [Fig-3]. The cells were uniform round to oval, with scanty eosinophilic cytoplasm. Nuclei were round with vesicular chromatin and indistinct nucleoli [Fig-4].

The tumour was seen invading into the adjacent structures adipose tissue and muscle. Mitotic activity, necrosis and perineural invasion were not noted. Based on the clinical presentation and histopathology the diagnosis of PLGA was made. On immunohistochemistry tumour cells showed diffuse and intense immunoreactivity for S-100 protein [Fig-5]. CD-117 is weak and focally positive [Fig-6].

DISCUSSION: PLGA accounts for about $2 \%$ of all salivary gland tumours and occurs almost exclusively in the minor salivary glands. ${ }^{[1,2]}$ 
The commonest site of occurrence is the palate, followed by buccal mucosa, upper lip, retromolar area, base of tongue and lacrimal gland.[4] The age at the time of the diagnosis of PLGA ranges from 16 to 94 years, with a mean age of 59 years and with a female predilection. ${ }^{[1]}$ The tumour ranges in size from $0.4 \mathrm{~cm}$ to $6 \mathrm{cms}$ in the greatest dimensions, with a mean of $2 \mathrm{cms} .{ }^{[1,2]}$ Grossly, most tumours are circumscribed but non- encapsulated.

Microscopically, the three most commonly observed patterns are tubular, trabecular and solid nests. The polymorphic nature of the lesion refers to a variety of growth patterns which includes simple tubules, complex or fused tubules, trabeculae, single-cell files, targetoid swirls, solid nests, fascicles, and cribriform, papillary, or papillary-cystic structures. [5]

Tubules are lined by cuboidal/ columnar isomorphic cells; spindly or polygonal with moderate amount of bland cytoplasm having round, pale nuclei with inconspicuous nucleoli. The chromatin varies from vesicular to stippled. The cribriform plates appear as islands of tumour cells around clear spaces that are empty or filled with mucoid material. Sometimes targetoid pattern is formed by concentrically arranged cords and narrow tubules of cells.

Papillary or papillary-cystic pattern consists of dilated cysts with small intraluminal papillary projections. Mucinous or clear cells are occasionally seen. Myoepithelial cells are absent or focally present on light microscopy. The tumour cells are surrounded by hyalinised eosinophilic stroma. The stroma may also appear as myxoid or slate-gray blue. Few cases may show psammoma bodies or crystalloids.

Because of its morphological variations, PLGA has often been misdiagnosed as Pleomorphic adenoma (PA) or Adenoid cystic carcinoma (ACC). ${ }^{6]}$

\begin{tabular}{|l|l|l|l|}
\hline \multicolumn{1}{|c|}{ Characteristic } & \multicolumn{1}{|c|}{ PLGA } & \multicolumn{1}{c|}{ ACC } & \multicolumn{1}{c|}{ PA } \\
\hline Cells & Epithelial & Epithelial & $\begin{array}{l}\text { Epithelial and } \\
\text { Myoepithelial }\end{array}$ \\
\hline Nuclear features & $\begin{array}{l}\text { Homogenous, pale and } \\
\text { vesicular nuclei. }\end{array}$ & $\begin{array}{l}\text { Condensed, angulated } \\
\text { and hyperchromatic } \\
\text { with high N: C ratio. }\end{array}$ & $\begin{array}{l}\text { Pale, uniformly } \\
\text { granular } \\
\text { chromatin. }\end{array}$ \\
\hline Stroma & Hyaline, fibrosclerotic & $\begin{array}{l}\text { Hyaline, fibrous, } \\
\text { mucoid }\end{array}$ & $\begin{array}{l}\text { Chondromyxoid, } \\
\text { mucoid, } \\
\text { fibroblastic }\end{array}$ \\
\hline Mitotic activity & Infrequent & Rare \\
\hline $\begin{array}{l}\text { Morphological diversity } \\
\text { pattern }\end{array}$ & $\begin{array}{l}\text { Present- Extensive } \\
\text { Tubuloglandular, } \\
\text { trabecular, papillary, } \\
\text { cystic, cribriform }\end{array}$ & $\begin{array}{l}\text { Present-Limited } \\
\text { Cribriform structure } \\
\text { much more common. } \\
\text { Glandular lumina } \\
\text { absent. }\end{array}$ & Present \\
\hline Infiltrative margins & Present & Present & Variable \\
\hline Perineural invasion & Present & $\begin{array}{l}\text { Present-Early \& } \\
\text { extensive }\end{array}$ & Absent \\
\hline Malignant potential & Low & High & Benign \\
\hline Metastasis & $\begin{array}{l}\text { Regional lymph nodes are } \\
\text { more commonly involved } \\
\text { than distant metastasis. }\end{array}$ & $\begin{array}{l}\text { Distant metastasis to } \\
\text { lungs, bone, and soft } \\
\text { tissue is more common } \\
\text { as compared to } \\
\text { regional lymph nodes. }\end{array}$ & No \\
\hline \hline
\end{tabular}




\begin{tabular}{|l|l|l|l|}
\hline Recurrence rate & Low (9-17\%) & High & Variable \\
\hline Immunohistochemistry & $\begin{array}{l}\text { S-100:Strong } \\
\text { intensively positive } \\
\text { CD-117: Weak and focal. }\end{array}$ & $\begin{array}{l}\text { S-100:Patchy and less } \\
\text { intense } \\
\text { CD-117: Strong and } \\
\text { more diffuse. }\end{array}$ & P63, calponin \\
\hline Proliferative Index & Ki67-low & Ki67-high & Ki67-low \\
\hline Prognosis & Good & Poor & Good \\
\hline \multicolumn{2}{|l|}{ Table 1: Differentiating features between PLGA, ACC and PA } \\
\hline
\end{tabular}

Pleomorphic adenoma can be differentiated from PLGA by its non-infiltrative nature, presence of myoepithelial cells, prominent chondromyxoid stroma and presence of plasmacytoid hyaline cells. ACC can be distinguished from PLGA by the presence of tumour cells with high N: C ratio, hyperchromatic angulated nuclei and basophilic cytoplasm. Cribriform structures are much more common in ACC. The tumour cells are immunoreactive with vimentin, cytokeratin, S-100 protein, CEA, SMA and glial fibrillary acidic protein (GFAP). [7]

PLGA invades locally to the nearby maxillary sinuses, nerves and has a potential to cause bone resorption. ${ }^{[8]}$ Metastasis to cervical lymph nodes is uncommon with incidence of $5-15 \%$ usually seen in tumours with papillary configuration. Local recurrence and regional metastasis rates are 9-17\% and $9-15 \%$ respectively, which may occurs many years after initial treatment.

Surgical excision is the treatment of choice for PLGA. [1, 9] Sometimes wide local excision to a more radical procedure (including maxillectomy, hemimandibulectomy and orbital excenteration) may be required. The overall prognosis for PLGA is favourable as compared to ACC with literature reporting 95\% people alive after 10 years. ACC has more aggressive clinical behaviour with extensive local invasion and higher frequency of vascular metastasis to lungs and bones and with multiple recurrences.

CONCLUSION: PLGA is a unique salivary gland neoplasm arising almost exclusively in minor salivary glands. PLGA has clinical and histopathological variations. PLGA has slow rate of growth, minimal aggressiveness and low metastatic potential and a favourable prognosis after conservative treatment. Salivary gland tumours like pleomorphic adenoma, adenoid cystic carcinoma mimics PLGA, recognition of histopathological clues favour its diagnosis.

\section{REFERENCES:}

1. Sunil V Jagtap et al. Polymorphous Low Grade Adenocarcinoma Presenting as Recurrent Oral Ulcerations. Journal of Clinical and Diagnostic Research. 2012 (Suppl-2), 6 (4): 712-714.

2. Thompson LD. Polymorphous Low-Grade Adenocarcinoma. Pathology Case Reviews 2004; 9: 259-263.

3. Arathi N, Bage AM. Polymorphous low-grade adenocarcinoma of parotid gland: A rare occurrence. Indian J Pathol Microbiol 2009; 52: 103-105.

4. Olusanya AA, Akadiri OA, Akinmoladun VI, Adeyemi BF. Polymorphous Low Grade Adenocarcinoma: Literature Review and Report of Lower Lip Lesion with Suspected Lung Metastasis. J Maxillofac Oral Surg.2011; 10(1): 60-63.

5. Siddharth Gupta et al. Polymorphous Low -grade Adenocarcinoma of Palate. International Journal of Head and Neck Surgery. 2011; 2(1): 57-60. 


\section{CASE REPORT}

6. Gupta R, Gupta K, Gupta R. Polymorphous low grade adenocarcinoma of the tongue: a case report. Journal of Medical Case Reports.2009:3:9313.

7. Krishnamurthy A, Vaidhyanathan A, Majhi U. Polymorphous low-grade adenocarcinoma of the parotid gland. J Can Res Ther 2011; 7: 84-87.

8. Mahnaz Fatahzadeh. Palatal polymorphous low grade adenocarcinoma: Case report and review of diagnostic challenges. Arch Orofac Sci 2012; 7(2): 92-100.

9. Kazuko T, Ricko D, Kazunori K, Motoki N, Masayuki S, Fumihiro O, et al. Polymorphous low grade adenocarcinoma arising at the retromolar region: a rare case of high grade malignancy. Yonogo Acta Medicine.2007; 50:17-22.

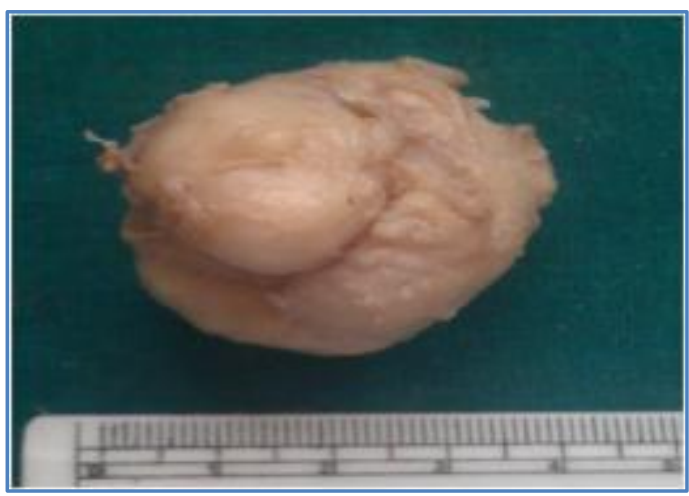

Fig. 1: Well-circumscribed, firm palatal mass

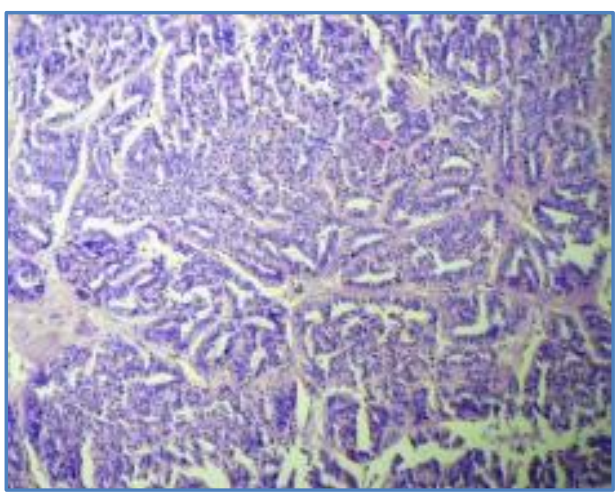

Fig. 2: Cells arranged in tubules, Trabeculae and nests. (10x, H\&E)

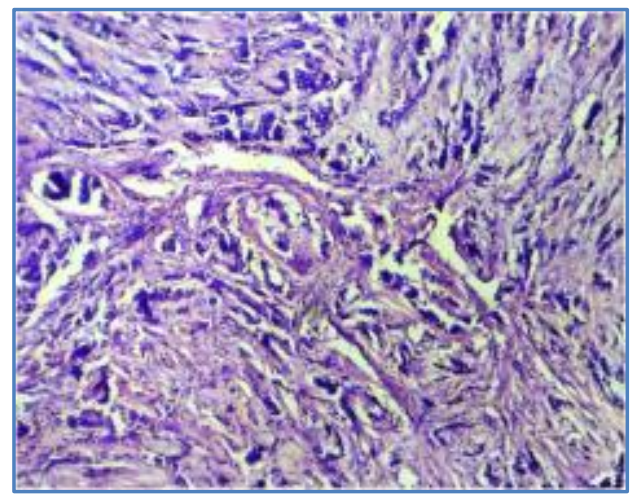

Fig. 3: Showing small nests, Indian file pattern separated by fibrosclerotic stroma. (10x, H\&E)

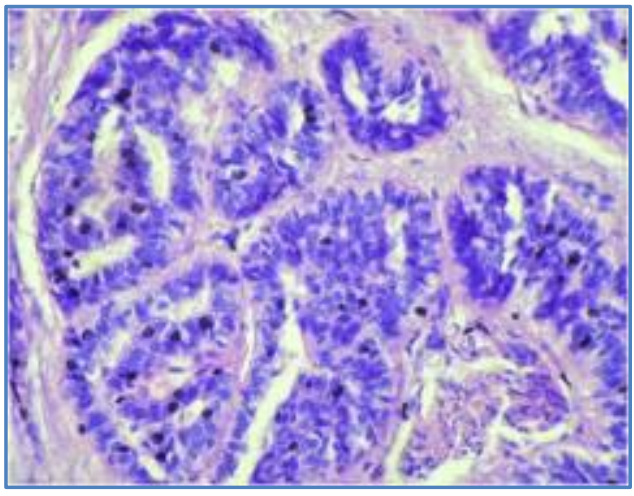

Fig. 4: Showing uniform tumor cells having round to oval nuclei with vesicular chromatin, indistinct nucleoli and scanty eosinophilic cytoplasm. (40x, H\&E) 


\section{CASE REPORT}

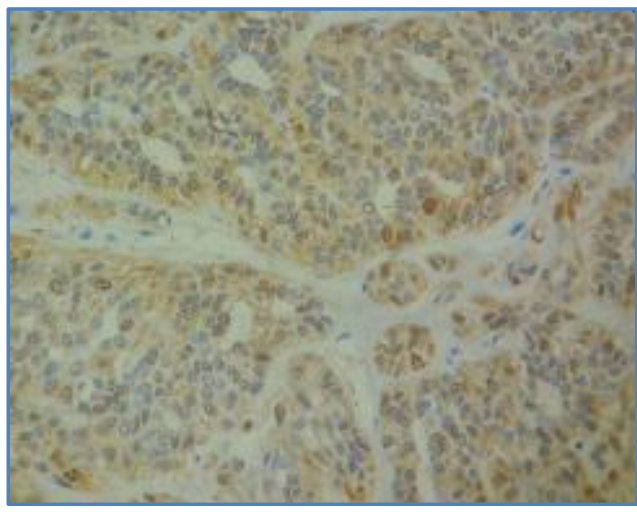

Fig. 5: IHC showing tumor cells strongly positive for $S-100$. (40x, H\&E)

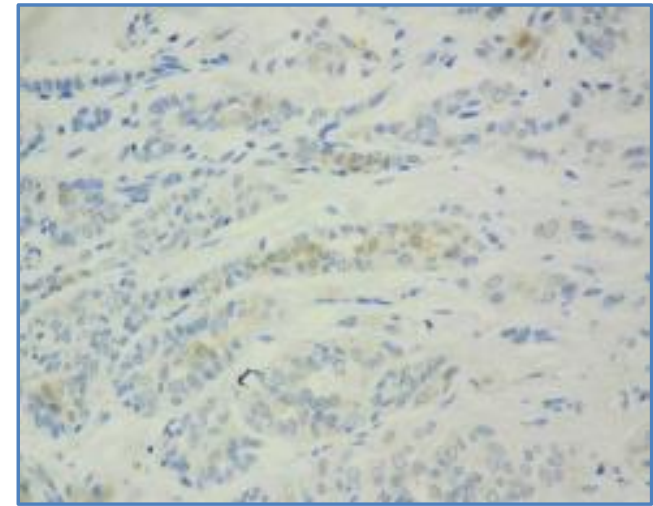

Fig. 6: IHC showing tumor cells weak and focal positive for CD-117. (40x, H\&E)

\section{AUTHORS:}

1. Swapnil D. Chandekar

2. Sunita S. Dantkale

3. Rahul R. Narkhede

4. Snehal V. Chavhan

5. Khushboo Birla

\section{PARTICULARS OF CONTRIBUTORS:}

1. Post Graduate Student, Department of Pathology, Government Medical College, Latur.

2. Associate Professor and HOD, Department of Pathology, Government Medical College, Latur.

3. Assistant Professor, Department of Pathology, Government Medical College, Latur.

4. Post Graduate Student, Department of Pathology, Government Medical College, Latur.

5. Post Graduate Student, Department of Pathology, Government Medical College, Latur.

\section{NAME ADDRESS EMAIL ID OF THE CORRESPONDING AUTHOR:}

Dr. Swapnil Devidas Chandekar, Department of Pathology, $3^{\text {rd }}$ Floor, College Building, Government Medical College, Latur-413512.

Email: swapnildoc.chandekar@gmail.com

Date of Submission: 07/08/2014. Date of Peer Review: 08/08/2014. Date of Acceptance: 12/08/2014. Date of Publishing: 18/08/2014. 